\title{
The Development of National Law Based on Constitutional Court Decisions
}

\author{
Irfan Nur Rachman ${ }^{1}$ \\ \{irfan.nrachman@gmail.com\} \\ ${ }^{1}$ Department of Research Center and Case Examination, and Library Management of \\ The Constitutional Court, Indonesia
}

\begin{abstract}
Indonesia is a country that adopts a civil law system. The main source of law for states that adopt a civil law system is the law. After amendment 1945 constitution which occurs in 1999 until 2002 and the Constitutional Court was born in 2003 because of its amendment 1945 constitution. There is a new source of law that has a very strategic role in efforts to develop a national legal system, namely the Constitutional Court's Decision. The Constitutional Court's decisions often contain orders, recommendations, and prohibitions to form legislators to amend laws that are declared unconstitutional. Sometimes, The Constitutional Court was ignored by the legislator. It means that The Constitutional Court decision has not a primary source of law. This paper aims to discuss the character of the Constitutional Court decision and how is the concept of national legal development based on the Constitutional Court decision. The method used in this study is juridical-normative through the regulatory approach and case study approach. According to the research result, the character of the Constitutional Court decision is final and binding. The judicial policy or judicial order must be put in the planning of development of national law document.
\end{abstract}

Keywords: Constitutional Court, Judicial Order, Legal Development

\section{Introduction}

Before the amendment of 1945 Constitution, the development of law based on two sources of material law, namely the pre-independence material legal source and the post-independence material legal source. As for the material sources of pre-independence material law consisting of (1) customary law, as a living law that has lived and developed in Indonesian society; (2) religious law both Islamic law and other religious law; (3) Dutch law; (4) Japanese law. Whereas post-independence legal material sources consist of: (1) international legal instruments; (2) legal developments in the civil law system; (3) legal developments in the common law system [1]. However, after changing the constitution there is a new source of law that must be considered in the development of domestic law.

The implications of the amendment 1945 Constitution have already created several new state institutions, [2] one of a new state institution is the Constitutional Court which was born as a result of the constitutional supremacy which adopted after the amendment of the 1945 Constitution [3]. Based on Article 24C paragraph (1) of the 1945 Constitution, The Court has 4 (four) authorities and 1 (one) obligation, namely: The Court has the authority to adjudicate at 
the first and last level whose decisions are final for:

(1) testing the law against the Constitution;

(2) decide upon disputes over the authority of state institutions whose authority is granted by the Constitution;

(3) decide upon the dissolution of political parties; and

(4) decide upon disputes over the results of general elections.

Meanwhile, the Constitutional Court shall render a judgement on the petition of the People's Representative Council regarding an alleged violation by the President and/or Vice President have violated according to the Consitution. The Court also gained additional authority to decide on disputes over the results of the election of governors/mayors/regents based on Article 157 paragraph (3) of Law Number 8 of 2015 concerning Amendment to Law Number 1 of 2015 concerning the Establishment of Government Regulations in lieu of Law Number 1 of 2014 concerning the Election of Governors, Regents and Mayors into law as amended lastly through Act Number 10 of 2016 concerning the Election of Governors, Regents and Mayors.

One of the functions of the Constitutional Court is creating a mechanism of checks and balances between state institutions so that there is no abuse of authority in the administration of the state as stated by Lord Acton, "power tends to corrupt, absolute power is corrupt absolutely [4]. Herefore, as the implementation of the checks and balances function, if the law as a legislative product turns out to violate the constitution, it can be cancelled by the Constitutional Court. Aside from being a constitutional court, the Court is also known as a norm court. Due to the authority of the Constitutional Court in examining the constitutionality of a law.In its development, especially after the amendment to the 1945 Constitution, there is a new source of law which must be used as a guideline when reforming national law, namely the Constitutional Court's Decision. Normatively, the Constitutional Court has a negative legislative role which functions to annul norms in the law. According to Hans Kelsen, "The annulment of law is the legislative function, an act-so to speak-of negative legislation. A court which is competent to abolish laws-individually or generally-function as a negative legislature."[5] Meanwhile, the People's Representative Council and the President acted as a positive legislature because they functioned to make laws.

In general, Bagir Manan stated that efforts to renew colonial law were not only limited through the establishment of legislation but could also be through judges' decisions[6]. Especially after the change in the constitution, the 1945 Constitution currently has no explanation. Therefore, the Constitutional Court, which functions as the final interpreter of the constitution, plays a role in filling the vacuum of constitutional interpretation and making efforts to renew colonial law through its rulings.

Decisions on judicial review of the 1945 Constitution that have been made by the Constitutional Court against various submitted petition requests must be considered in efforts to develop national law, especially changes in legislation [7]. The Constitutional Court's decision contains elements of legal politics so it is crucial to be accommodated in the national legal planning document. The Constitutional Court's decision often guides legislators on how and where the development of domestic law is carried out. Sometimes the Constitutional Court acts as a positive legislature because the Constitutional Court does not only state that a legal norm is contrary to the constitution and not legally binding, but also formulating the norm through conditionally constitutional or conditional unconstitutional decisions. According to Alec Stone, the Court's involvement in the legislative process by formulating rules in its decision could also be referred to as judicialization of politics. The following is Alec Stone's full opinion [8]. 
"Judicialization of politics is the intervention of constitutional judges in legislative processes, establishing limits on law-making behaviour, reconfiguring policymaking environments, and sometimes, drafting the precise terms of legislations."

The Constitutional Court must now be seen as a law-making body other than the President and the Parliament. According to Jimly Asshiddiqie, this was seen as a convergence between legal systems. Because today there is a strong tendency in countries that adopt a common law system to give a greater role to the law as in the civil law system. On the contrary, in the civil law environment there is also an effort to enlarge the role of the court as a law-making institution [9].

However, in reality, the Constitutional Court's Decision is often ignored or the follow-up of its decision is not in accordance with the judicial legal politics or judicial order that have been decided by the Constitutional Court, thus causing a condition that is not harmonious between the Constitutional Court's decision and the intended law. Research conducted by Trisakti University regarding the level of compliance with the judicial review decision in the Constitutional Court by Addressat Decision. Decisions that became the object of study totalling 109 decisions were granted since 2013-2018. The following table complies with the Constitutional Court's decision [10].

Table

Level of Compliance with Judicial Verdicts 2013-2018

\begin{tabular}{|l|c|c|}
\hline \multicolumn{1}{|c|}{ Level of Compliance } & Total & Percentage \\
\hline Obeyed All & $\mathbf{5 9}$ & $\mathbf{5 4 , 1 2} \%$ \\
\hline Partially Obeyed & $\mathbf{6}$ & $\mathbf{5 , 5 0} \%$ \\
\hline Not Obeyed & $\mathbf{4 1}$ & $\mathbf{3 7 , 6 1 \%}$ \\
\hline Not Yet Known & $\mathbf{3}$ & $\mathbf{2 , 7 5} \%$ \\
\hline Total & $\mathbf{1 0 9}$ & $\mathbf{1 0 0}$ \\
\hline
\end{tabular}

Sources : Tri Sulistiyowati etc (Trisakti University)

From the table above it can be seen that the level of compliance with the Constitutional Court's decision by the addresat of the Constitutional Court's decision can be divided into four categories, namely:

(1) Decisions that have been complied with as many as 59 decisions $(54.12 \%)$;

(2) Decisions that were complied with were six decisions (5.50\%);

(3) Decisions not complied with 41 (37.61\%);

(4) Not yet known as many as three decisions (2.75\%).

This problem is a mutual concern. There fore, it is necessary to discuss two issues.

The article will discuss, first, the character of the constitutional court; Second, the concept of legal development based on the constitutional decision. Thus, the process of harmonization of laws and regulations from the upstream to downstream sectors occurs. 


\section{Method}

The method used in this study is juridical-normative through the regulatory approach and case study approach. The case study approach is carried out on a number of cases which contain the efforts of the Constitutional Court in carrying out the development and reform of national law.

\section{Result and Discussion}

\subsection{The Characteristics of The Constitutional Court Decision}

In the provisions of Article 24C Paragraph (1) of the 1945 Constitution it is only emphasized that the Constitutional Court's decision is final. There is no legal remedy that can be taken after the Constitutional Court's decision. This is also confirmed by the principle of res judicata pro veritate habetur which means that the judicial decision must be considered correct. On the other hand, the word "final" which come from article 24C of 1945 Constitution was derivated into several articles in the Constitutional Court Law. Article 10 Paragraph (1) of the Constitutional Court Law states, "The Constitutional Court has the authority to adjudicate at the first and final instance, whose judgment shall be final for following:..etc". The word "final" is explained at the explanation of Article 10 of the Constitutional Court Law. Its article stipulates, "The Constitutional Court's decision is final, that is, the Constitutional Court's Decision directly obtains permanent legal force since it is pronounced and no legal remedies can be taken." (ii) Article 47 of the Constitutional Court Law which states, "The Constitutional Court's decision to obtain permanent legal force since it was finished pronounced in a plenary session open to the public." (iii) Article 29 paragraph (1) of Law Number 48 the Year 2009 (Law on Judicial Power) which states, "The Constitutional Court has the authority to adjudicate at the first and last level whose decisions are final ... etc."

In addition to the Constitutional Court Law and the Judicial Power Law, the follow-up to the Constitutional Court's decision is also regulated in Law Number 12 the Year 2011 Regarding the Formation of Legislation Act, namely Article 10 paragraph (1) and paragraph (2) which states as follows.

"(1) The content of the material which must be regulated by Law contains:

a. further regulation on the provision of Constgitution of the Republic of Indonesia 1945;

b. instruction of the law for will be governed by Law;

c. ratification of certain international agreement;

d. The follow-up to the decision of the Constitutional Court; and/or

e. fulfill legal needs in the people;

(2) Follow-up on the decision of the Constitutional Court as referred to in paragraph (1) letter d shall be carried out by the Parliament or the President. "

Article 23 Paragraph (1) in Law Number 12 the Year 2011 Regarding the Formation of Legislation Act which states.

"(1) The Prolegnas contains open cumulative list consisting of:

a. Ratification of certain international agreement;

b. due to the decree of the Constitutional Court;

c. State Revenue and Expenditure Budget;

d. establisment, expansion, and merger of the Province and/or Regency/Municipality;and

e. determination/revocation of Government Regulation In Lieu of Law" 
Although in the 1945 Constitution, the Law on Judicial Power, and the Constitutional Court Law have been stated explicitly that the Constitutional Court's decision is final. However, this does not make the legislators fully obey the Constitutional Court's decision. The Constitutional Court Law only stipulates that the character of the Constitutional Court's decision is "final". With this formulation, apparently there is still neglect of the Constitutional Court's decision. Even in the amendment to the Constitutional Court Law, namely the enactment of Law Number 8 of 2011 concerning Amendment to Law Number 24 of 2003 concerning the Constitutional Court, there are articles which reduce the degree of the decision of the Constitutional Court. This article offers options to the legislators to be able to follow up or not follow up on the Constitutional Court's decision. The material referred to in the provisions contained in Article 59 Paragraph (2) which states, "If necessary changes to the law that has been tested, the Parliament or the President immediately follow up on the decision of the Constitutional Court as referred to in paragraph (1) in accordance with statutory regulations." but this article has been canceled by the Constitutional Court through Decision Number 49/PUU-IX/2011, dated October 18, 2011. In its legal considerations, the Court stated the following [11].

"... that the Constitutional Court's decision is final and binding on the public (erga omnes) which is directly implemented (self-executing). Decisions of the Constitutional Court are the same as laws which must be implemented by the state, all citizens and existing stakeholders. The norm of Article 59 paragraph (2) of Law 8/2011 is unclear and causes legal uncertainty because the People's Representative Council and the President will only follow up on the Court's decision if necessary. Even though the Court's decision is a final and binding decision which must be followed up by the Parliament and the President as a form of constitutional system based on the 1945 Constitution as well as a consequence of constitutional democratic state ideology ... "

In other words, the legislators are obliged to implement the Constitutional Court's decision, and there is no room for not implementing the Constitutional Court's decision. This decision reinforces and emphasizes that there is no other choice for legislators, except to implement what the Constitutional Court has decided. There are also other questions, whether by doing so, the legislators (the Parliament and the President) have limited authority by having an obligation to implement the Constitutional Court's decision. According to Howard Ball who stated that the Act as a product of the political process tested by the Constitutional Court as an authority applied to prevent policy processes that could deviate far from the constitutional mandate, so that undemocratic institutions such as the Constitutional Court actually help and support democratic majoritarianism by insisting urging political institutions to act within the framework of power referred to in the constitution, so that when formulating laws taking into account existing constitutional boundaries. Howard Ball's opinion confirms the existence of the Constitutional Court which functions to formulate constitutional boundaries through constitutional interpretation in each of its decisions [12]. Indeed, in a democratic perspective, the legislators have the authority to regulate all aspects of life through the legislative process by interpreting the constitution, but whenever there is a Constitutional Court ruling that contains the interpretation of the constitution, then in the context of the rule of law, the legislator must follow the constitutional interpretation made by the Constitutional Court .

In 2012 there was a request to the Constitutional Court in examining the constitutionality of the articles related to the follow-up to the Constitutional Court's decision. First, the Article 10 Paragraph (1) of the Constitutional Court Law states, "The Constitutional Court has the authority to decide at the first and last level whose decisions final ... etc. " Second, The Article 47 of the Constitutional Court Law states, "The Constitutional Court's decision to obtain permanent legal 
force since it was finished pronounced in a plenary session open to the public." Third, Article 29 paragraph (1) of Law Number 48 the Year 2009 (Law on Judicial Power) which states, "The Constitutional Court has the authority to adjudicate at the first and last level whose decisions are final...etc." These articles, according to the Petitioner, are unconstitutional because they do not contain the phrase "and must be implemented". In other words, the Petitioner intends to add the phrase "and must be implemented". The absence of this phrase, according to the Petitioner, is unconstitutional.

However, through Decision Number 105/PUU-XIV/2016 states that the Petitioners' petition cannot be accepted because the Petitioners do not suffer constitutional impairment. Even though the decision is not acceptable, the Court has assessed and considered the constitutionality of the articles being petitioned. The Court stated that theoretically and practically, with the statement "final and binding" a judge's decision had a message and at the same time the meaning that the decision must be implemented [13].

The Constitutional Court also emphasized that the nature of the Constitutional Court's verdict in judicial review is a declaration of the constitution. That is, the Court only declared a norm contrary or not to the constitution. If the Constitutional Court declares a certain norm or part of the law contrary to the constitution, the Constitutional Court will state that the norm will be declared to have no binding legal force. At the same time, the judicial review decision also contains constitutive nature because in the decision, a legal condition is absent or a new legal state is formed [14].

On the other hand, according to Maruarar Siahaan, in the judicial review decision, some decisions were self-implementing and non-implementing. Self-implementing decisions contain the meaning that the Constitutional Court's decision can be implemented immediately after being announced in a public hearing and announced in the State Gazette as a new legal norm that can be implemented quickly. Meanwhile, there are also constitutional court decisions that are non-implementing implementing a new legal policy. Implementation of this new legal policy requires a new legal basis as the basis for implementing public policies that have been determined in the Constitutional Court's decision [15].

Meanwhile, according to Maria Farida Indrati, the Basic Rules are contained in the 1945 Constitution, the People's Consultative Assamby Decree and in the basic unwritten law which is often referred to as the Constitutional Convention. These Basic Rules of the Country are the basis for the formation of the Law (formell gesetz) and other lower regulations [16]. One of the Basic Rules of the State in the context of norm hierarchy theory is the 1945 Constitution. In the stufen theory, the Constitutional Court's decision is not included in the norm hierarchy structure which according to Hans Nawiasky consists of:

1) State fundamental norms (staatsfundamental norm);

2) Basic Rules of the State (staatsgrundgesetz);

3) Formal Act (formell gesetz), and

4) Implementation and Autonomy Regulations (Verordung \& Autonome Satzung), because the Constitutional Court's decision is not included in the regulation family, but is included in the verdict category. However, the Constitutional Court's decision often includes the interpretation and explanation of the 1945 Constitution in its legal considerations, namely:

1. Decision Number 001-021-022/PUU-I/2003 concerning Judicial Review of Law Number 20 The Year 2002 concerning Electricity which interprets the phrase "statecontrolled" and the phrase "production branches" contained in Article 33 of the 1945 Constitution. 
2. Decision Number 066/PUU-II/2004 concerning Judicial Review of Law Number 24 of 2003 concerning the Constitutional Court and Law of the Republic of Indonesia Number 1 of 1987 concerning the Chamber of Commerce and Industry. The Constitutional Court interpreted Article 24C of the 1945 Constitution. It gave the message to legislators that the law must not reduce the authority of a state institution whose power is regulated by the constitution.

3. Decision Number 005/PUU-IV/2006 concerning the review of Law Number 22 of 2004 concerning the Judicial Commission and Testing of the Law of the Republic of Indonesia Number 4 of 2004 concerning Judicial Power which interprets the phrase authority "the judge" and the phrase "other authorities "In Article 24B paragraph (1) of the 1945 Constitution relating to the authority of the Judicial Commission. The Constitutional Court also gives direction to legislators to carry out legal reforms by making integrative improvements in the law on the Judicial Commission and harmonizing and synchronizing the Judicial Power Law, the Judicial Commission Law, and the Law Constitutional Court.

4. Decision Number 10/PUU-VI/2008 concerning the review of Law Number 10 of 2008 concerning General Elections. The Constitutional Court interpreted Article 22C paragraph (1) The 1945 Constitution is related to the conditions of domicile of members of the Regional Representative Council which are constitutional norms so that there must be a requirement for nominating members of the Regional Representative Council.

5. Decision Number 11/PUU-VIII/2010 concerning Judicial Review of Law Number 22 the Year 2007 concerning General Election Organizer where the Constitutional Court interpreted the sentence "a general election commission" in Article 22E paragraph (5) of the 1945 Constitution. According to the Constitutional Court interpretation, the word "An election commission" does not refer to one institution, but rather refers to the function of organizing elections that are national, permanent, and independent. It's clarified the position of the Election Supervisory Body and Election Supervisory Board in the electoral legal system in Indonesia, namely as the elections organizer.

6. Decision Number 92/PUU-X/2012 concerning the Testing of Law Number 27 of 2009 concerning the People's Consultative Assembly, the People's Representative Council, the Regional Representative Council, and the Regional People's Representative Council and Law Number 12 of 2011 concerning the Formation of Legislation. In this decision, the Constitutional Court has reconstructed and strengthened the authority of the Regional Representative Council (DPD) in the legislation process.

Some examples of the above decisions have confirmed the Court's position as an interpreter of the constitution and played an active role in determining the political direction of constitutional law. Sometimes, the Constitutional Court has made changes to the constitution through its judicial interpretation mechanism. For example, in Decision Number 2-3/PUU-V/ 2007, the Court affirmed that in the context of narcotics crime, the right to life could be reduced and limited by Article 28J of the 1945 Constitution. This is different from what has been regulated in Article 28I paragraph (1) The 1945 Constitution which states that the right to life is a right that cannot be reduced under any circumstances. In The decision Number 138/PUU- 
VII/2009, the Constitutional Court also affirmed having the authority to examine government regulations in lieu of laws (Perpu) that are not regulated in the constitution.

In exercising its constitutional authority to examine laws against the 1945 Constitution, the Constitutional Court often clarifies the meaning of the 1945 Constitution by giving an interpretation of the articles in the 1945 Constitution after the amendment. Because of the effect of its amendment, the 1945 Constitution no longer recognizes any "explanation".

However, the absence of the explanation potentially makes the 1945 Constitution a string of textual sentences without meaning. According to Ronald Dworkin, one method of interpreting the constitution is by using "moral reading". This method rests on the basis upon which to understand the constitution as moral principles of dignity and justice [17].

Meanwhile, to ensure that the 1945 Constitution can adjust to the times and changes in society, there needs to be an institution that interprets it. In this position, all institutions may have an interpretation of the 1945 Constitution. Still, based on Article 24C paragraph (1) of the 1945 Constitution, one of the Constitutional Court's authorities is to examine the law against the 1945 Constitution, so that only the Constitutional Court acts as the final interpreter of the constitution. That is, all parties must submit to the interpretation of the constitution made by the Constitutional Court.

From the description of the Constitutional Court's decision above, it is clear that the Constitutional Court's decision that interprets the constitution has a function as an "explanation of the Constitution". It becomes a guideline for the legislators to implement the constitution by making laws based on the Constitutional Court's decision. Especially because the current 1945 Constitution no longer has an explanation. Based on the theoretical perspective, the position of the Constitutional Court's decision can be aligned with the constitution. Because of its function as an interpretation and explanation of the constitution. Even in certain cases, it can change the constitution through its judicial interpretation mechanism.

\subsection{Concept of National Law Development}

In general, the development of the national legal system is based on the Proclamation of Independence of the Republic of Indonesia as the starting point for the development of the national legal system. It is based on the 1945 Constitution in which the preamble and the articles in the constitution contain the objectives, grounds, constitutional ideals, and basic norms the Indonesian state which must be the goal and foundation of the development of the national legal system. In the fourth paragraph of the opening of the 1945 Constitution set forth the purpose of the establishment of the Indonesian state, namely: [18]

"... protect all Indonesians and all Indonesian blood and to promote public welfare, educate the nation's life, and participate in carrying out world order based on independence, eternal peace and social justice, the Indonesian National Independence was compiled in an Indonesian Constitution. It was formed in an arrangement of the Republic of Indonesia which sovereignty of the people based on the Almighty God, Humanity that is just and civilized, Indonesian Unity and Popularity led by wisdom in Consultative/Representative, and by realizing social justice for all Indonesian people. "

In order to support and realize the ideals of the Indonesian people, a national legal development system was developed based on the proclamation and the 1945 Constitution. However, the dynamics of the state administration of Indonesia after the reforms changed along with changes in law and society. The change in law was marked by a constitutional amendment that took place in the period 1999 to 2002. A judicial power institution other than the Supreme Court was born, namely the Constitutional Court which played a role in strengthening the 
mechanism of checks and balances between branches of state power to avoid irregularities. In other words, the presence of the Constitutional Court with its constitutional review function is tasked with ensuring that the law made has consistency, coherence, and corresponds to the 1945 Constitution as the supreme law of the land. The legal position of the Constitutional Court's ruling as an explanation of the 1945 Constitution helped direct the direction of national law development because it appeared that the Constitutional Court's decision contained important judicial legal politics or judicial order in the legislative process.

The concept of planning, development and renewal of the national legal system based on the Constitutional Court's decision is needed because after the reformation, and our country has had the Constitutional Court which initially functioned as a negative legislature, now shifting towards the positive legislature. It means, originally the Constitutional Court was only tasked with abolishing norms, but now it is formulating new norms. In fact, often the legal considerations section contains judicial legal politics or judicial order that include orders, messages, prohibitions, and permissions to the legislators in making laws. Based on case data obtained from the Registrar's Office and the General Secretariat, in the period 2003 to 2016, the Court has decided 954 cases of judicial review with the following details of the case:

Table

The Decision Since 2003-2016

\begin{tabular}{|c|c|l|l|l|l|}
\hline \multicolumn{7}{|c|}{ CASES } \\
\hline Granted & Decline & $\begin{array}{l}\text { Not } \\
\text { Acceptable }\end{array}$ & Fall & Pulled Back & $\begin{array}{l}\text { Not } \\
\text { Authority }\end{array}$ \\
\hline 222 & 331 & 281 & 16 & 98 & 6 \\
\hline
\end{tabular}

Sources : The Registrar and The Secretariat General of The Constitutional Court

Based on the table above, there are 222 decisions which stated that the petition was granted. This means that there are at least 222 norms declared by the unconstitutional Court, including decisions that abolish norms, conditional unconstitutional and conditional constitutional decisions. Conditional cancellation or interpretation of these norms is a particular concern for lawmakers in planning and developing law.

Although in theory, Indonesia adheres to civil law. However, the convergence between the legal systems is unavoidable because there is a strong tendency in countries that adopt a judgemade law or common law system to give a greater role to the law as in the civil law system. On the contrary, in the civil law environment there is also an effort to enlarge the role of the court as a law-making institution. According to Natabaya, although in civil law system, the law is an important and primary source of law, but because the drafting of laws is increasingly difficult to follow the acceleration of the legal needs of the community, due to social, economic and technological changes that are very fast. It is necessary to fill the written legal vacuum developed permanent jurisprudence [19].

The next question is how to make the Constitutional Court's decision taken into account in the planning and development of the national legal system. According to a research report by Ni'matul Huda and friends regarding the Formulation of the Concept of Follow-Up to the Judgment of the Judicial Review of the Law by the Constitutional Court. There are a variety of legal products as a follow-up to the Constitutional Court's ruling Laws, Government Regulations, Presidential Regulations, Presidential Decrees, Supreme Court Regulations, Ministerial Regulations, Supreme Court Circular Letters, Minister Circular Letters, Circular 
Director General of the Ministry, General Election Commission Regulations, Circular Letters of the General Election Commission, Election Supervisory Body Regulations, and Regional Regulations [20]. Whereas according to Article 10 paragraph (1) letter d in Law Number 12 the Year 2011 Regarding the Formation of Legislation Act Law, the follow-up to the Constitutional Court's decision is one of the material content that must be regulated by law [21].

According to this research, the obligation to follow up the Constitutional Court's decision with the legal container of the law is often distorted by the addresat of the Constitutional Court's decision. For example, when the Constitutional Court overturned the Law on Elections, the addresat of the Constitutional Court's decision regarding this matter was the General Election Commission. A follow-up to the Constitutional Court's decision by the General Election Commission in general by making the General Election Commission Regulation related to the Constitutional Court's decision without waiting for changes to the Election Law [22].

In Indonesia, referring to Sunaryati Hartono's opinion, judicial decisions are a source of law. However, the role of the judiciary as a law-making institution is still secondary with the presence of the Constitutional Court as a judicial institution authorized to examine the constitutionality of a law and function as the final interpreter of the constitution. Whether the Constitutional Court's decision as a source of law-making is also secondary. This certainly can be seen and measured from the extent to which the Constitutional Court's decision affects the law making process. Whether the interpretation of the articles in the 1945 Constitution and the interpretation of the material content of norms in a law so as not to conflict with the 1945 Constitution by the Constitutional Court has been used as a guide to determine the direction of legal politics or judicial order in the development of the national legal system or not.

Table

The Concept of Law Development Based on The Constitutional Court Decision

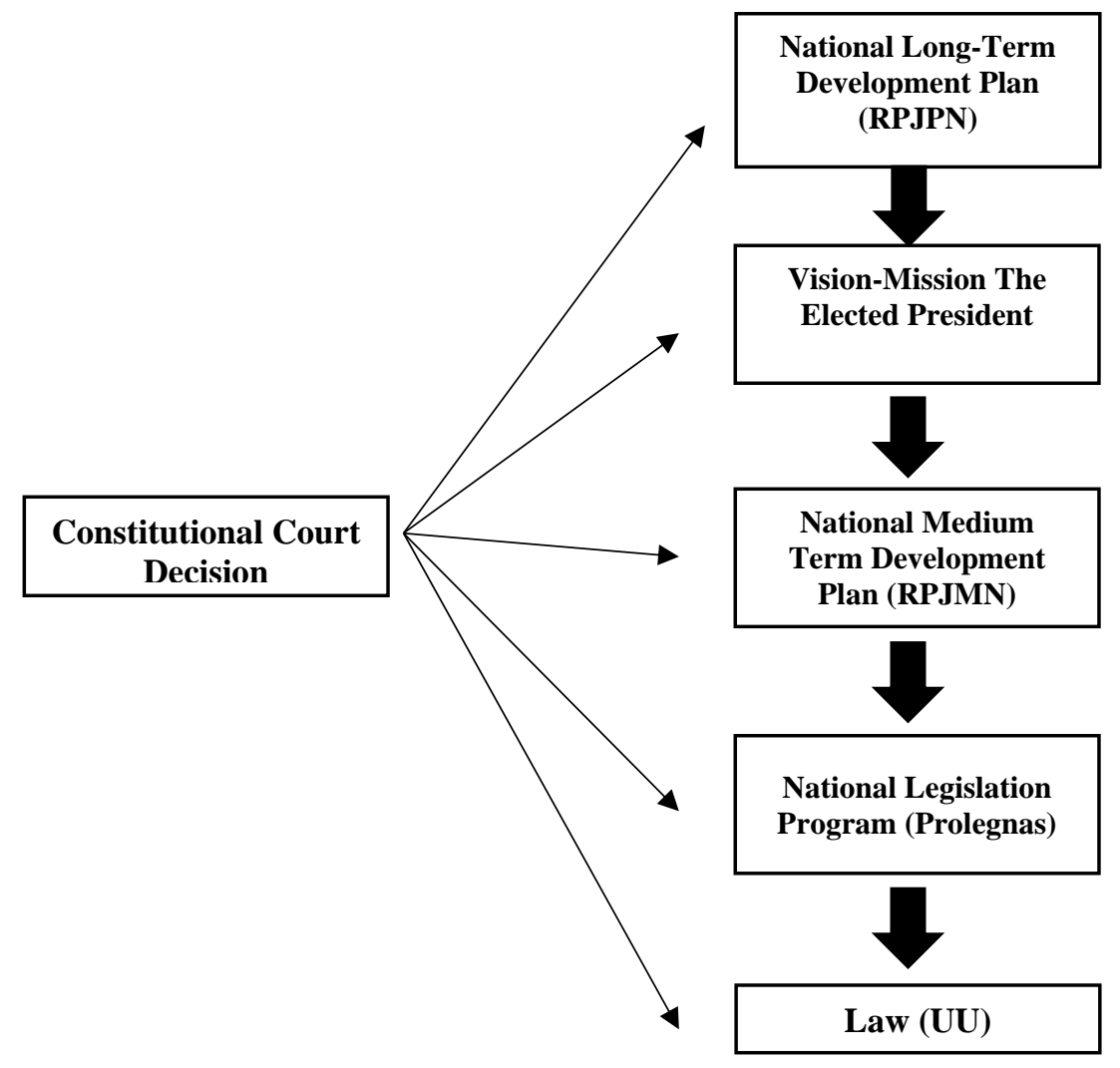


Based on the table above, the concept of planning and national law development must be based on the Constitutional Court's decision. Previously, the Constitutional Court's decision was only used as a second source in planning and updating national law whereas the legal position of the Constitutional Court's decision as described in the previous section has a strategic position in the effort to develop national law.

Some things that need to be done to conceptualize the development and renewal of the national legal system based on the Constitutional Court's decision are:

a. Conduct an inventory of judicial legal politics or judicial order in the Constitutional Court's decision, both in decisions where the grants are granted, rejected or not acceptable. Why is it also necessary to pay attention to decisions that are rejected and unacceptable when both types of decisions do not cause a new legal situation or negate new legal conditions, so they are not ordered to be published in the State Gazette. Only decisions that have been granted have to be published in the Official Gazette. If that is the rule contained in Article 57 paragraph (3) of the Constitutional Court Law which states, "The Constitutional Court's decision that grants the mandatory application must be published in the State Gazette no later than 30 (thirty) working days after the verdict is pronounced." Therefore, decisions which are rejected and unacceptable are not a concern of the legislators.

b. On the other hand the rejected decision or unacceptable decision has potentially contained the politics of judicial law or judicial order. For example, the authority of the Constitutional Court to test the Perpu because according to the Constitutional Court the Perpu has the same legal force as the law contained in the decision of Decision Number 138/PUU-VII/2009 where the "unacceptable" ruling is accepted. An inventory of "judicial legal politics or judicial order" should be carried out by legislators (the DPR and the President) with their respective authorities.

c. After the legislators have a database on the list of "judicial legal politics or judicial order", what needs to be done is to determine the priority scale of "judicial legal politics" to be included in the open cumulative list.

d. After the legislators have a database on the list of "judicial legal politics or judicial order", what needs to be done is to determine the priority scale of "judicial legal politics or judicial order" to be included in the open cumulative list.

e. It is necessary to declare the importance of the Constitutional Court decision to the National Long-Term Development Plan (RPJPN) as a reference in the framework of planning, development and national law reform. The National Long-Term Development Plan (RPJPN) is a national development planning document that plays a role in determining the direction of the country's development in the next 20 years. The National Long-Term Development Plan (RPJPN) is also a substitute for the outline of the direction of the state (GBHN) which includes national development directions, 
including development in the legal sector. Therefore, the importance of The National Long-Term Development Plan (RPJPN) emphasizes the importance of the Constitutional Court's decision in the planning and development of the national legal system.

f. The National Medium Term Development Plan (RPJMN) is a manifestation of the vision and mission of the elected President that contains the direction of national law development. Therefore, judicial legal politics or judicial order in the Constitutional Court's decision is important to be used as a guide and reference for the elected President in the planning, development and reform of national law as it is known that all aspects of domestic life are regulated in the Law. The National Medium Term Development Plan (RPJMN) is an instrument for carrying out national legal development, one of which is developed in the Legal Field. Even considering the importance of the RPJMN in national even, during the nomination of the 2019 presidential and vice-presidential candidate pair, the General Election Commission and the Ministry of National Development Planning (PPN/Bappenas) held a technocratic design for the 2020-2024 RPJMN. According to Bambang Brodjonegoro (PPN Minister/Chairperson of Bappenas) at the event, the vision and mission of the elected presidential candidate pair will be translated into RPJMN 2020-2024 [23].

g. The dynamics of state administration in each period of national development must be used as a reference in national development in the next period, including development in the legal sector. The RPJMN contains a "regulatory framework" that contains policies in all fields. In this context, the Constitutional Court's decision, which was decided during the previous RPJMN periodization, should be a reference in the preparation of the next RPJMN. Therefore it is important to make an inventory of judicial legal politics or judicial order in the Constitutional Court's decision to put in the regulatory framework in the RPJMN document. Therefore, during the preparation of the National Legislation Program whose source is the RPJMN, the judicial legal politics or judicial order contained in the Constitutional Court's decision was poured into the regulations to be made. Thus a harmonious condition will occur so that later licensed products are made that do not conflict with the constitution because the rules drawn up are based on the Constitutional Court's decision.

h. In the preparation of the National Legislation Program, the judicial legal politics or judicial order contained in the Constitutional Court's decision must be used as the main guideline in developing the "policy direction".Prolegnas is a national legal development planning document that contains the legal politics of national law development. Therefore, it is crucial to put the politics of judicial law or judicial order included in the decisions of the Constitutional Court in the documents referred to, so that between regulations there is mutual consistency, coherence, and correspondence with the 1945 Constitution as the highest law. When formulating the policy direction of law should be guided by the politics of judicial law or judicial order made by the Constitutional Court. The decision of the Constitutional Court whose ruling states that the application is unacceptable or rejected, for example, Decision Number 138/PUU- 
VII/2009 (Requirements for the Interest of Forcing and the Authority of the Court to examine The Perpu) and Decision Number 2-3/PUU-V/2007 (Constitutionality of capital punishment) need to be observant to map and carry out an inventory not only of the Constitutional Court's decision which was granted, but also of the Constitutional Court's decision which stated the application was unacceptable and the Constitutional Court's decision which stated the request was rejected.

\section{Conclusion}

From the discussion above, two things that constitute a conclusion, namely, first, the decision of the Constitutional Court is final and binding. Therefore, the judicial order in the constitutional court decision include prohibitions, suggestions, permissions, recommendations or messages is binding on all parties. Second, in the context of legal formation, decisions of the Constitutional Court are binding on the legislators in making laws and must pay attention to the decisions of the Constitutional Court as the primary source of law in the formation of law. This is in line with current developments where there are symptoms of convergence between legal systems. In countries that adopt a civil law system, there is an effort to enlarge the role of the judiciary as a law-making institution. Vice versa, in countries that adopt the common law system, there is an effort to enlarge the role of the law as in the civil law system.

\section{Acknowledgements}

The author wishes to thank the Secretary-General,The Registrar, and The Head of Departement of Research Center and Case Examination, and Library Management of The Constitutional Court of Indonesia to support this paper and for providing facilities to join an International Conference of Indonesian Legal Studies (ICILS 2020) UNNES.

\section{References}

[1] Arief Hidayat, Pancasila Sebagai Kaidah Penuntutun Dalam Pembentukan Hukum Nasional, delivered at the National Seminar with the theme, "Questioning: Regulation of Health Workers in the Draft Law on Health Personnel", November 16, 2013 at Soegijapranata Catholic University, Semarang.

[2] State institutions that were born after the amandement of the 1945 Constitution namely the regional representative Council, the constitutional court and the judicial commission. While the state institution that was abolished in the 1945 constitution was the supreme advisory Council.

[3] With the adoption of the idea of the supremacy of the constitution that historically faced with the doctrine of parliamentary sovereignty, the Constitutional Court with its constitutional review authority was authorized to guarantee that the legal products must not be in conflict with the 1945 constitution. See. Jimly Asshiddiqie, Model Pengujian Konstitusional di Berbagai Negara, Jakarta:Konstitusi Press,2006.

[4] Jimly Asshiddiqie, Konstitusi dan Konstitusionalisme, Jakarta: Sekretariat Jenderal dan Kepaniteraan Mahkamah Konstitusi, 2005.

[5] Hans Kelsen, General Theory of Law and State, New York: Russel \& Russel, 1973. 
[6] Bagir Manan, Teori Dan Politik konstitusi, Cet.Kedua, Yogyakarta: FH UII Press,2004.

[7] Jimly Asshiddiqie, Konstitusi dan Konstitusionalisme, Jakarta: Sekretariat Jenderal dan Kepaniteraan Mahkamah Konstitusi, 2005.

[8] Alec Stone Sweet,Governing with Judges: Constitutional Politics in Europe, Oxford University Press, New York, 2002).

[9] Jimly Asshiddiqie, Hukum Tata Negara Dan Pilar-Pilar Demokrasi: Serpihan pemikiran Hukum, Media dan HAM, (Jakarta: Konstitusi Press, 2005.

[10] Tri Sulistiyowati,"Constitutional Complience Atas Putusan Pengujian Undang-Undang Mahkamah Konstitusi oleh Adressat Putusan”, Laporan penelitian Fakultas Hukum Trisakti, 2019.

[11] Paragraph [3.11] number 9 Decision Number 49/PUU-IX/2011 concerning Judicial Review of Law Number 8 of 2011 concerning Amendment to Law Number 8 of 2011 concerning amandement to law Number 24 of 2003 concerning the Contitutional Court.

[12] Howard Ball, Courts And Politics, The Federal Judicial System, Precentice-Hall Inc, Englewood Cliffs, N.J.1980.

[13] Paragraph [3.9.4] Decision Number 105/PUU-XIV/2016 concerning Judicial Review of Law Number 24 of 2003 that has been amended by Law Number 8 of 2011 concerning Amendment to Law Number 24 of 2003 concerning the Constitutional Court, Law Number 48 of 2009 concerning Judicial Power and Law Number 30 of 2014 concerning Government Administration.

[14] Paragraph [3.9.4] Decision Number 105/PUU-XIV/2016 concerning Judicial Review of Law Number 24 of 2003 that has been amended by Law Number 8 of 2011 concerning Amendment to Law Number 24 of 2003 concerning the Constitutional Court, Law Number 48 of 2009 concerning Judicial Power and Law Number 30 of 2014 concerning Government Administration.

[15] Maruarar Siahaan, Implementasi Putusan Mahkamah Konstitusi Dalam Pengujian Undang-Undang Studi Tentang Mekanisme Checks And Balances di Indonesia, Disertasi,2010.

[16] Maria Farida Indrati, Ilmu Perundang-Undangan: Jenis, Fungsi, dan Materi Muatan, Yogyakarta: Kanisius, 2007.

[17] Ronald Dworkin, Freedom's Law: The Moral Reading of the Constitution, New York: Oxford University Press Inc., 2005.

[18] The Preambule of the 1945 Constitution of the Republic of Indonesia.

[19] H.A.S Natabaya, Menata Ulang Sistem Peraturan Perundang-Undangan Indonesia, Jakarta: Sekretariat Jenderal dan Kepaniteraan Mahkamah Konstitusi.

[20] Ni'matul Huda, Formulasi Konsep Tindak Lanjut Putusan Pengujian Undang-Undang Oleh Mahkamah Konstitusi Yang Bersifat Mengatur, Research Report, Yogyakarta: Indonesia Islamic University, 2019.

[21] See. Elucidation of Article 10 paragraph (1) letter d of Law Number 12 of 2011 concerning Formation of Regulations.

[22] Ni'matul Huda, Formulasi Konsep Tindak Lanjut Putusan Pengujian Undang-Undang Oleh Mahkamah Konstitusi Yang Bersifat Mengatur, Research Report, Yogyakarta: Indonesia Islamic University, 2019.

[23] https://nasional.kompas.com/read/2018/09/25/14174651/ketua-bappenas-visi-misicapres-cawapres-harus-sesuai-rpjm-nasional, Accessed on March,15th 2020. 